p.174

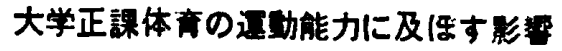

山口大学袖 非洛 治

1. 緒言 新制大学発足と其心, 体青が必修科目とし て採択されて 8 ケ年を経猧した。その間大学当吕はもと より, 文部省大学学術局, 大学体育協䠣会, 大学体育研 究集会, 日本体育学会などの機関が，相倚り相援けて， 满足とは言えないまでも，施設の充実，用具の整俑，教 官の増員；指導方法の改善などに努力を払つて，大学体 䏍が次第に向上していることは采知の通りであるが，果 して如何程の 效果をあげているのか，昭和 31 年山口大

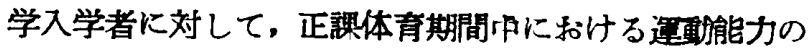
推移を継続的に調查して，その動態を把握しようとした ものである.

2. 調查項目

1. 垂淔跳（跳躍力）

ロ・サイドステップ（敏挂性）10秘間 巾1米（女 90 硬)

八. 体前屈（柔軟性）

=. 連続片脚跳（持久力） 20 米折返 1 分間（女 30 秒間）

\section{3. 調查の时間}

1. 第 1 回 入学直後 (31 年 4 月下旬)

口. 第 2 回 1 期終了後（31 年 10 月下旬）

八. 第 3 回 2 期終了後 (32 年 4 月中旬)

二. 第 4 回 3 期終了後 (32 年 9 月下旬)

4. 調查の対象

昭和 31 年度山口大学入学者全員.

\section{5. 調查の結果}

第し表 正課体方斯间中にお゙ける基動 能力の推移

山口大学炤和 31 年入学

\begin{tabular}{|c|c|c|c|c|c|c|}
\hline & 世21月1日月 & Den & 179 & E & +4 & 104 \\
\hline \multirow{4}{*}{$\begin{array}{l}2 \\
8 x\end{array}$} & $A \%$ & \multirow{3}{*}{$\begin{array}{r}500 A \\
(19-\lambda)\end{array}$} & 51.49 & 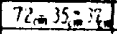 & $5.60_{m m}$ & 0.109 \\
\hline & $1 \%$ & & 53.00 & $71-36-35$ & 5.69 & 0.107 \\
\hline & 2 & & 53.17 & $78-40-38$ & 9.58 & 0.107 \\
\hline & 3 每 & 431 & 53.41 & $74-10-36$ & 5.62 & 0.105 \\
\hline \multirow{4}{*}{ 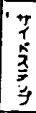 } & $A \neq 89$ & \multirow{3}{*}{$\begin{array}{c}500 \\
(3-\lambda)\end{array}$} & $18.61 \mathrm{~h}$ & $29-11613$ & 2.210 & 0.120 \\
\hline & 1 跑 & & 21.28 & $79-15-14$ & 2.31 & 0.108 \\
\hline & 20 & & 2.03 & $31-16 \cdot 15$ & 2.75 & 0.1996 \\
\hline & 3 足 & 431 & 2284 & $32 \cdot 18-14$ & $? .73$ & 0.048 \\
\hline \multirow{4}{*}{ 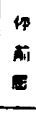 } & $\lambda$ 明 & \multirow{3}{*}{$\begin{array}{c}500 \\
13-0.1\end{array}$} & 43.56 & $\sin 26-37$ & $5930 \pi$ & 0.137 \\
\hline & 1 角 & & 46,45 & $60-30-3 n$ & 4.91 & 0.106 \\
\hline & $2 \%$ & & 47.67 & $61-31 \cdot 27$ & 0.12 & 0.102 \\
\hline & $3 \%$ & 411 & 48.15 & $60-33 \cdot 27$ & 5.11 & 9106 \\
\hline \multirow{4}{*}{$\underset{\mathbf{n}}{E}$} & 入甲 & \multirow{3}{*}{$\begin{array}{l}500 \\
n-8,1\end{array}$} & 172.45 & $205-120=85$ & 10.609 & 0.796 \\
\hline & 10 & & 180.51 & $20 A-130 \cdot 78$ & 12.44 & 0.069 \\
\hline & $2 m$ & & $184: 1$ & $21 A-130.04$ & 13.21 & $0.07 i$ \\
\hline & 31 & $43 !$ & $B \geq ? 3$ & \begin{tabular}{|l|l|l|l|l}
215 & $154 \cdot 6$ \\
\end{tabular} & 1.41 & 0.956 \\
\hline
\end{tabular}

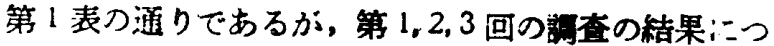
てな。，比較の関保上 3 回共実施して者についてのみ採 り上け，化汇除いてある。

6. 調查の信頼抄

1. 要領は正しいか，第 2 表上段の入学㭙における 全国大学との比較によつてもわかるように，その桔果の 数值が極めて類似していることから推して，要領は正し いものと思われる.

第 2 表運動能力の比敕

山口大学と全国大学

（入学時）

沿和 31 年度々炤和 32 年变（一期役）

\begin{tabular}{|c|c|c|c|c|c|c|}
\hline & & $\operatorname{sing} 2$ & 410 & & 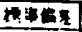 & lonse \\
\hline \multirow{2}{*}{9} & 山Otz & $500 \mathrm{~A}$ & 51.19 & $12=\overline{3}=37$ & $50 \mathrm{~cm}$ & 0.133 \\
\hline & 金大等 & 5670 & 51.3 & $74-3 ; \cdot 14$ & 6.55 & 0.120 \\
\hline \multirow{2}{*}{$\overrightarrow{\underline{E}}$} & $40 \div$ & 500 & 18.510 & $23 \times 1418$ & $2.23 \mathrm{~g}$ & 0.120 \\
\hline & 19?7 & 6253 & 18.54 & $30-8.72$ & 3.08 & 0.166 \\
\hline \multirow{2}{*}{ 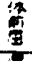 } & 4 L大 & 500 & $\Delta 353$ & $57=22 \times 35$ & 5.95 & 0.37 \\
\hline & S907\% & 5598 & 04.59 & $64-20-64$ & 5.94 & 0.133 \\
\hline \multirow{2}{*}{$\frac{3}{3}$} & 屾龵 & 500 & $17245_{\mathrm{T}}$ & $205-120=85$ & $16.60 \mathrm{~m}$ & 0.096 \\
\hline & 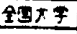 & 5767 & 16825 & $212-102+110$ & 19.48 & 0.1 .16 \\
\hline \multirow{2}{*}{ 贯 } & $3 ! 1 \times 3$ & 500 & 5300 & $7 L_{\sin } 36 ; 35$ & $5.69 \mathrm{~m}$ & 0.007 \\
\hline & $327 \lambda$ & 65 & 5303 & $63-39 \cdot 2 d$ & 5.87 & 0.111 \\
\hline \multirow{2}{*}{$\begin{array}{l}\frac{7}{2} \\
\frac{1}{4} \\
\end{array}$} & $317 \lambda$ & 500 & 21.20 & $29 \times 15-14$ & 2.310 & 0.100 \\
\hline & $32 \pi \times 4$ & 65 & 2208 & $27-17-10$ & 1.80 & 0.082 \\
\hline \multirow{2}{*}{8} & 317.27 & 500 & 4625 & $60-30-30$ & $4.9 \mathrm{~km}$ & 2.106 \\
\hline & $327 \wedge$ & 65 & 47.28 & $59-38-21$ & 4.58 & 0.096 \\
\hline & $317 \lambda \%$ & 500 & $180.51 \mathrm{~m}$ & $200-130-72$ & $12.4 \mathrm{Am}_{\mathrm{m}}$ & 0.069 \\
\hline & $327 \lambda$ 学 & 65 & 181.85 & $205-100-65$ & 12.88 & 0071 \\
\hline
\end{tabular}

ロ テストずれによる記䩮の向上が入つてはいない か，第 2 表下段 32 年度入学者を 10 月上旬 (初旬)。抽出 （月明 3，4 時很展攸者）して調查したのであるが，それ を 31 年度入学者の第 2 回目の調查に比㜞すると,テス トずれでなく，何れる1期传には同程度の这能力の向 上をあらわしていることがわかる。

7. 結語 侣本調查は次の計画によつて内容を分析榆 討している.

入学時の結果について

1. 浪人年数によつて如何に異るか,

口. 出身地域によつて如何に異るか,

‥ 課外体目実施状況によつて如何に異るか，

入学後の向上について

1. 出席の良否によつて如何に異るか，

ロ、展修人員の多少によつて如何に異るか，

八. 体育実施万法によつて如何に異るか,

二. 課外体育実施状況によつて如何に異るか，

これらの検討の結果报後的の結論を得られると思う が、これについては, 次の機会に報告することにする。 